\title{
IMPLEMENTASI PENGEMBANGAN SOFT SKILL MAHASISWA PGMI DALAM PEMBELAJARAN SAINS DI MIN 1 WONOSARI YANG BERVISI KARAKTER BANGSA
}

\author{
Moh. Agung Rokhimawan \\ (Dosen Prodi.PGMI FITK UIN Sunan Kalijaga Yogyakarta)
}

\begin{abstract}
The development of science and technology today is very fast, it can not be dammed again, and in fact all elements of society feel the impact of these developments. With the advancement of science and technology now Indonesian society in general forced to literacy Saintek to sustain life in the present and future. The results of a survey conducted in the UK showed that about $30 \%$ of workers use science in some aspects of his work. This situation is expected to continue to increase from year to year. The results of a similar survey also showed that competence is most often used by workers is the competence to solve problems, work in teams, and communicate. The second survey showed a similar thing, which both point to the same three competencies: problem solving, working in teams, and communicate. It's all included components Soft Skill. The method used is the method of development up to implementation. demonstrated that the results of observation in science learning that has been implemented in MIN 1 Wonosari got an average score of 115 with a good category " $B$ ". And the formation of character is evident in perubahanya include : increased student atusias, curiosity has been growing, encouraged to work together in groups and are encouraged to problem solving.
\end{abstract}

Keyword: Soft skill, science instruction, living education

\section{A. PENDAHULUAN}

Perkembangan sains dan teknologi sekarang ini sangat cepat, sudah tidak dapat dibendung lagi dan bahkan semua elemen masyarakat merasakan dampaknya dari perkembangan tersebut. Dengan kemajuan sains dan tekhnologi sekarang masyarakat indonesia pada umumnya dipaksa untuk melek saintek untuk mempertahankan hidup dimasa sekarang dan yang akan datang. Dengan kemajuan saintek masyarakat indonesia menjadi lebih dimudahkan dalam bekerja atau dimanjakan dengan teknologi sekarang, jangan sampai dengan kemajuan teknologi malah menjadi neraka bagi mereka yang belum melek saintek. Di era globalisasi sekarang ini persaingan saintek dan pendidikan di sekolah dasar semakin tajam dan cepat perubahannya. Dalam paradigma pendidikanpun sudah mulai berubah dari Teaching center berangsur-angsur berubah ke Student Centered Learning, dan 
Touching untuk pendidik, serta mengajak siswa bisa belajar dengan baik dan berkelanjutan.

Di era sekarang, ada konsep yang disebut sebagai pendidikan soft skill, yang di dalam bahasa gampangnya disebut sebagai pendidikan yang memiliki relevansi dengan kemampuan pribadi seseorang. Melalui pendidikan soft skill tersebut, maka seorang peserta didik diajarkan agar memiliki kemampuan berkomunikasi dan bersosialisasi dengan lingkungan sosialnya.1

Isu-isu yang berkembang dikampus saat pelaksanaan pelatihan guru dalam jabatan atau biasa disebut PLPG banyaknya guru-guru khususnya guru MI belum memiliki kemampuan pribadi yang baik sehingga akan berdampak pada peserta didik di sekolah. Untuk itu perlunya pengembangan soft skill bagi calon guru MI dalam pembelajaran sains MI bervisi karakter bangsa. Dalam rangka mempersiapkan calon guru MI yang profesional dan berkepribadian yang baik.

Menurut (Rurtherford and Ahlgren, 1990) Pendidikan sains dapat menolong peserta didik untuk mengembangkan dan kebiasaan berpikir yang diperlukan sebagai manusia yang memiliki tenggang rasa yang dapat berpikir untuk dirinya sendiri dan bangsanya. Pendidikan sains juga harus mempersenjatai mereka ketika berpartisipasi menyumbangkan pemikiran dengan sesama warga negara untuk melindungi masyarakat yang sangat terbuka, sehingga dalam keadaan bahaya. ${ }^{2}$

Undang-undang no. 20 tahun 2003 tentang Sistem Pendidikan Nasional pasal 3 menyatakan bahwa : Pendidikan Nasional berfungsi mengembangkan kemampuan dan membentuk watak serta peradaban bangsa yang bermartabat dalam rangka mencerdaskan kehidupan bangsa. Terbentuknya karakter peserta didik yang kuat dan kokoh diyakini merupakan hal penting dan mutlak dimiliki peserta didik untuk menghadapi tantangan hidup masa depan. ${ }^{3}$

Beberapa pimpinan perguruan tinggi negeri di indonesia mengeluh tetang persoalan moral, karakter atau akhlak yang dihadapi sehari-hari. Kalau kita sadari bahwa kita mendapat tugas tambahan yang amat berat dan bakan lebih berat dari tugas pokonya. Tugas tambahan tersebut adalah

${ }^{1}$ Nur Syam. Pendidikan Soft Skill, Artikel ilmiah 2010 diakses pada tanggal 20 Desember 2010 http:// nursyam.sunan-ampel.ac.id/?p=1585. hlm. 2

2Liliasari. Membangun Masyarakat Melek Sains Berkarakter Bangsa Melalui Pembelajaran. 2011.

Makalah Seminar Nasional, pada tanggal 16 April 2011 Prodi Pendidikan IPA S1 FPMIPA Universitas Negeri Semarang. Hlm. 3

${ }^{3}$ UU no. 20 tahun 2003 tentang Sistem Pendidikan Nasional pasal 3. 
bagaimana membina moral, karakter atau akhlak bagi para mahasiswa. Ada tiga masalah yang menyedihkan dikampus adalah:

1. Masih ada mahasiswa yang melakukan pergaulan bebas berlebihan.

2. Masih ada mahasiswa yang mengkonsumsi narkoba atau obat-obatan terlarang.

3. Masih ada mahasiswa yang selalu tawuran dikampusnya.

Tiga hal tersebut diatas menggambarkan betapa pentingnya bagi kita semua ikut peduli terhadap pendidikan dan masa depan bangsa ini. Kita semua yakin bahwa betapapun kualitas kecerdasan para siswa dan bahkan juga sarjana, jika tidak dibarangi dengan moral, karakter dan akhlak yang luhur, maka apapun yang diraih dari usanya dalam pendidikan, tidak memberikan makna apa-apa, baik terhadap dirinya sendiri maupun terhadap bangsanya. orang cerdas dan trampil tetapi tidak diikuti oleh moral, karakter dan akhlak yang luhur, justru akan menjadi kekuatan perusak yang lebih dasyat daripada orang yang tidak berpendidikan.4

Hasil survei yang dilakukan oleh Council of Science and Technology di Inggns menunjukkan bahwa sekitar 30\% pekerja menggunakan sains dalam beberapa aspek pekerjaannya. Keadaan ini diperkirakan akan terus meningkat dari tahun ke tahun. ${ }^{5}$ (Gott \& Duggon, 1996; Wiyanto: 2011) Hasil survei tersebut juga menunjukkan bahwa lebih dari 1000 industriawan mengidentifikasi tiga kompetensi yang diperlukan industri, yaitu kompetensi yang terkait dengan bekerja ilmiah, berkomunikasi, dan manajemen. ${ }^{6}$

(Heuvelen, 2001; Wiyanto: 2011) Hasil survei serupa juga dilaporkan oleh American Institute of Physics di Amerika Serikat. Hasilnya menunjukkan bahwa kompetensi yang paling sering digunakan oleh pekerja adalah kompetensi memecahkan masalah (problem solving), bekerjasama dalam tim, dan berkomunikasi.7

Ada dua hal yang menarik untuk diperhatikan dari kedua hasil survei tersebut. Pertama, karena bekerja ilmiah terkait dengan upaya memecahkan masalah dan bekerjasama dalam tim juga merupakan aspek manajemen, maka sebetulnya kedua hasil survei menunjukkan hal yang serupa, yaitu keduanya menunjuk pada tiga kompetensi yang sama: problem

${ }^{4}$ Imam Suprayogo, Mengintegrasikan Nilai-Nilai Lubur Dalam Pendidikan Sains Untuk. Menyongsong Masa Depan Bangsa, 2010. Makalah Seminar Nasional, pada tanggal 23 Oktober 2010 PPS Universitas Negeri Yogyakarta.

5Wiyanto, Pembelajaran Sains Untuk Mengembangkan Karakter Unggul, Makalah Seminar Nasional, pada tanggal 16 April 2011 Prodi Pendidikan IPA S1 FPMIPA Universitas Negeri Semarang. hlm. 1

6Wiyanto, Pembelajaran Sains..., hlm.1

7Wiyanto, Pembelajaran Sains..., hlm.1 
solving, bekerjasama dalam tim, dan berkomunikasi. Kedua, walaupun survei dilakukan pada tempat dan waktu yang berbeda, namun keduanya menunjukkan hasil yang serupa. Hal ini menyiratkan bahwa hasil survei tersebut mengungkap gejala yang bersifat umum yang dapat berlaku di tempat dan waktu yang berbeda, dan mengindikasikan betapa penting penguasaan ketiga kompetensi itu. Dengan demikian ketiga kompetensi yang ditunjukkan oleh kedua survei dapat dijadikan sebagai penciri atau indikator keunggulan seseorang, yang dapat juga menjadi karakter keunggulan pribadinya. Ibarat tombak bermata tiga, ketiga kompetensi itu dapat dijadikan sebagai "senjata" untuk mempertahankan hidup yang layak sesuai tuntutan zaman, oleh karena itu ketiga komptensi ini kemudian saya sebut juga sebagai "trisula kompetensi". ${ }^{\circ}$

Berdasarkan latar belakang yang telah dikemukakan tersebut diatas, maka masalah penelitian yang akan dikaji adalah Bagaimana Implementasikan pengembangan soft skill mahasiswa PGMI dalam pembelajaran sains di MIN 1 Wonosari yang bervisi karakter bangsa?

\section{B. Pembahasan}

Dalam kamus bahsa indonesia soft artinya halus, lembut, atau lunak. Sedangakan skill adalah kecakapan, keterampilan atau kemampuan. Permintaan dunia kerja terhadap kriteria calon pekerja dirasa semakin tinggi saja. Dunia kerja tidak hanya memprioritaskan pada kemampuan akademik (hard skills) yang tinggi saja, tetapi juga memperhatikan kecakapan dalam hal nilai-nilai yang melekat pada seseorang atau sering dikenal dengan aspek soft skills. Kemampuan ini dapat disebut juga dengan kemampuan non teknis yang tentunya memiliki peran tidak kalah pentingnya dengan kemampuan akademik.

Menurut Elfindri dkk. soft skills didefinisikan sebagai berikut:

"Soft skills merupakan keterampilan dan kecakapan hidup, baik untuk sendiri, berkelompok, atau bermasyarakat, serta dengan Sang Pencipta. Dengan mempunyai soft skills membuat keberadaan seseorang akan semakin terasa di tengah masyarakat. Keterampilan akan berkomunikasi, keterampilan emosional, keterampilan berbahasa, keterampilan berkelompok, memiliki etika dan moral, santun dan keterampilan spiritual".?

8Wiyanto, Pembelajaran Sains..., hlm.1

${ }^{9}$ Elfindri dkk. Soft Skill Untuk Pendidik, (Jakarta: Baduose Media, 2011) hlm. 67 
Menurut pendapat Muqowin, soft skills yaitu perilaku personal dan interpersonal yang mengembangkan dan memaksimalkan kinerja manusia seperti membangun tim, pembuatan keputusan, inisiatif, dan komunikasi. Soft skills tidak termasuk keterampilan teknis seperti keterampilan merakit komputer. Dengan kata lain, soft skills mencakup pengertian keterampilan non-teknis, keterampilan yang dapat melengkapi kemampuan akademik, dan kemampuan yang harus dimiliki oleh setiap orang, apa pun profesi yang ditekuni. Profesi seperti guru, polisi, dokter, akuntan, petani, pedagang, perawat, arsitek, dan nelayan harus mempunyai soft skills. ${ }^{10}$

Menurut pendapat Hari, soft skill merupakan jenis ketrampilan yang lebih banyak terkait dengan sensitivitas perasaan seseorang terhadap lingkungan disekitarnya. Karena soft skills terkait dengan ketrampilan psikologis, maka dampak yang diakibatkan lebih abstrak namun tetap bisa dirasakan seperti misalnya perilaku sopan, disiplin, keteguhan hati, kemampuan untuk dapat bekerja sama, membantu orang lain, dan sebagainya. ${ }^{11}$

Menurut Saldi, soft skill merupakan kemampuan-kemampuan dasar yang perlu ditumbuhkan dalam diri anda, agar anda dapat memotivasi diri dan orang lain, bertanggung jawab, membangun relasi, berkomunikasi, negosiasi, beradaptasi dengan lingkungan, berkreasi, berinovasi dan berwirausaha, memimpin, membangun kerjasama, mengelola sumber daya dan lain sebagainya. ${ }^{12}$

Menurut Tasman Hamami, soft skill adalah keterampilan seseorang dalam berhubungan dengan orang lain (Interpersonal skill) dan keterampilan dalam mengatur dirinya sendiri (Intrapersonal skill) yang mampu mengembangkan unjuk kerja secara maksimal. ${ }^{13}$

Jadi definisi soft skill adalah suatu keterampilan pribadi atau individu yang perlu dikembangkan oleh calon guru MI dalam berhubungan dengan orang lain (Interpersonal Skill) dan keterampilan dalam mengatur dirinya sendiri (Intrapersonal Skill) yang mampu mengoptimalkan pengembangan unjuk kerja secara maksimal.

${ }^{10}$ Muqowin, Pengembangan Soft Skill Guru.( Yogyakarta: Pedagogia, 2011) hlm. 5

${ }^{11 D j o k o}$ Hari Nugroho. Integrasi Soft Skills Pada Kurikulum Prodi Elektronika InstrumentasiSTTN Untuk Persiapan SDM PLTN, Makalah Seminar Nasional V SDM Teknologi Nuklir Yogyakarta, 5 November 2009. hlm. 118

${ }^{12}$ Saldi Fadli , Sinergi Soft Skill dan Hard Skill, diakses tanggal 20 desember 2010 http://edukasi.kompasiana.com/2010/02/23/sinergi-soft-skill-dan-hard-skill/

${ }^{13}$ Tasman Hamami. Pengembangan Soft Skill Bagi Guru Profesional, Makalah Pembekalan sertifikasi guru dalam jabatan UIN Sunan Kalijaga Yogyakarta 2010. Hlm. 2 
Hard skills lebih terkait dengan kemampuan seseorang secara teknis dalam menyelesaikan tugas-tugas tertentu menurut profesi masingmasing. Hard skill adalah penguasaan ilmu pengetahuan, teknologi dan keterampilan teknik yang berhubungan dengan bidang ilmuanya. Contohnya : seorang insinyur mesin seharusnya menguasai ilmu dan teknik permesinan; seorang dokter harus memupuni bidang ilmu kedokteran, seorang pendidik atau guru harus menguasai teknik didaktikmetodik dan menguasai bidang ilmunya.

\section{Atribut-Atribut Soft Skill}

Beberapa atribut soft skill antara lain: Komitmen, inisiatif, jujur, tanggungjawab, kemampuan untuk belajar, handal, percaya diri, kemampuan berkomunikasi, antusias, berani mengabil keputusan, itegritas, gigih atau motivasi untuk meraih prestasi, berlaku adil, berkreasi, kemampuan beradaptasi, kerjasama dalam tim, berfikir kritis, menghargai (pendapat) oranglain, kemampuan berorganisasi, kemampuan memimpin, Toleran, sopan, beretika.

Dalam soft skill terbagi menjadi dua yaitu interpersonal skill dan intrapersonal skill. Dua jenis keterampilan ini yang perlu diasah dapat dirinci sebagai berikut :

\section{a. Intrapersonal Skill}

Contoh penjelasan soft skill yang tergolong intrapersonal skill yang harus dikembangkean oleh guru meliputi :

Change management (Manajemen Perubahan) mari kita lihat perubahan dengan kekuatan cinta menurut Ibrabim Elfiky, ada tiga komponen keekuatan cinta, yaitu memaafkan, mencintai, dan memberi. Memaafkan berarti kemauan untuk menerima kesalahan orang lain yang dilakukan kepada kita. Proses memafkan melibatkan kekuatan spiritual, emosional, mental dan fisik. Hanya orang dengan tingkat spiritual yang tinggi yang mau memaafkan, sebab secara manusiawi orang akan mempertabankan egonya sendiri. Memaafkan melibatkan kekuatan emosional. Orang yang memaafkan harus mampu menahan segala emosi negatif yang pernah dia terima akibat perbuatan orang lain. Ketika dia mau memaafkan orang lain, maka dia harus mampu menundukkan semua emosinya sendiri. Memaafkan melibatkan kekuatan fisik, artinya seseorang harus menunjukkan sikap legowo menerima kesalahan orang lain. Kekuatan cinta menggerakkan seseorang untuk mengerjakan aktifitas profesi dengan penuh semangat, sebab motivasi muncul dari dalam (endogen), bukan dari luar (eksogen). Indikator kalau kita mencintai profesi adalah kita memberikan yang terbaik, memaafkan ketika ada kesalahan, dan mencintai semua yang terkait dengan 
pendidikan, terutama peserta didik dengan sepenuh hati. Ujian kekuatan cinta adalah ketika menghadapi persoalan, apakah kita putus asa atau tetap semangat. ${ }^{14}$

\section{b. Interpersonal Skill}

Contoh penjelasan soft skill yang tergolong intrapersonal skill yang harus dikembangkan oleh guru meliputi :

Communication skills atau keterampilan komunikasi bisa lisan dan tulisan.

Keterampilan berkomunikasi merupakan dasar utama (corner stone) soft skill dengan berkomunikasi manusia dapat cepat beradaptasi dengan lingkunganya dimanapun ia tinggal. Keberadaan setiap orang ditentukan oleh kemampuannya berkomunikasi dengan orang lain secara efektif.

Keterampilan komunikasi dengan tulisan dapat ditafsirkan sebagai unkapan atau ekspresi isi hati dan pikiran seseorang dalam tulisan. Dan dengan tulisan seseorang dapat menindikasikan kecakapan orang tersebut. Kesalahan dalam penulisan akan berdampak pada penulis dan biasa merusak image penulis.

Beberapa keterampilan komunikasi yang harus dilatih dan dibiasakan oleh peserta didik dan pendidik antara lain :

1) Questioning skill, keterampilan bertanya merupakan salah satu keterampilan yang sangat penting dalam pembelajaran sains dan dijadikan keterampilan utama yang harus dilatih. Berbagai penemuan yang dilakukan para ilmuan selalu dimulai dari menemukan masalah dan menyatakan masalah tersebut dalam sebuah pertanyaaan yang baik dan benar. pembelajaran sains hendaknya memberikan keterampilan kepada peserta didik untuk bertanya dan menemukan masalah. Bagaimana kita mengasah keterampilan bertanya pada teman-teman kita dikelas, disekolah, dirumah, dimasyarakat dan orang lain disekitar kita.

2) Body language, bahasa tubuh seperti wajah, mata, gerakan tubuh dll. Wajah adalah cermin dari pikiran, perasaan dan menggambarkan perhatian seseorang, menunjukkan kepada orang lain tentang apa yang kita pikirkan dan rasakan. Body language termasuk tampilan berdiri, duduk, rilek, tenang, dst. Dapat mencerminkan emosi dari penyampaian maupun penerimaan, seperti kejelasan berbicara, antusias. 
3) Presentation skills, keterampilan presentasi meliputi merencanakan, menyiapkan dan meyebarkan atau menyampaikan pesan. Bentuk ketarampilan presentasi dapat berupa : Pisik, lisan, dan multi media elektronik. Dalam pelaksanaan presentasi yang baik mengunakan visual yang bagus, baik gambar-gambar, warna, peta konsep, layout dan bahasa yang mudah dipahami.

4) Team work, Kerjasama TIM adalah sejumlah orang yang bekerja dengan tujuan bersama untuk menyelesaikan satu tugas. Keberhasilan organisasi (baca:sekolah) tergantung pada koordinasinya. Team work tercermin pada kesepakatan dan kerjasama antar anggota tim. Untuk bisa berkomunikasi dengan efektif dan empatik dalam tim, kita perlu mencermati prinsipprinsip team building. Ada tujuh prinsip dalam membangun tim atau yang disingkat dengan WEATHER, yaitu workout, empowerment, assistance, together, hand in hand, enable, dan respect. Workout berarti bekerja dalam kerangka pemikiran secara bersama. Empowerment berarti memberi kesempatan bagi anggota tim untuk memimpin. Assistance artinya memberi arahan dan bantuan. Together berarti melakukan sesuatu atas nama tim. Hand in hand bermakna bergandengan tangan dengan kompak dalam menjalani hari-hari penuh tantangan. Enable berarti membuat orang yang tidak bisa menjadi bisa. Yang tidak mampu menjadi mampu. Sementara itu, respect berarti adanya rasa saling menghormati dan meninggikan satu sama lain.

5) Professional ethics, etika profesi tercermin pada pelaksanaan tugas : misalnya seorang guru hanya berfikir tenteng pekerjaan mengajar saja, (tekun). Bekerja dengan sepenuh hati, memberikan kontribusi terhadap keberhasilan tugas sekolah, berfikir, apa yang bisa diberikan, bukan apa yang bisa diperoleh.

Sikap ilmiah ini bisa dikembangkan ketika siswa melakukan diskusi, percobaan, simulasi, atau kegiatan di lapanagan. Dalam hal ini, maksud dari sikap ingin tahu sebagai bagian sikap ilmiah adalah suatu sikap yang selalu ingin mendapatkan jawaban yang benar dari obyek yang diamati. Anak usia SD/MI mengungkapkan rasa ingin tahunya dengan jalan bertanya: kepada gurunya, temannya, atau kepada diri sendiri. Melalui kerja kelompok, maka "tembok ketidaktahuan" dapat dikuak untuk memperoleh pengetahuan.15

Dalam kerja ilmiah peserta didik wajib memiliki sikap ilmiah. Sikap ilmiah terdiri antara lain : 
1. Jujur, yaitu mengajukan data sebenarnya dari hasil penelitian tanpa mengubahnya, walaupun tidak sesuai dengan hipotesis dari teori.

2. Terbuka, yaitu dapat menerima perbedaan hasil yang didapat dengan teman lain atau ilmuwan lain dan teori baru dari experimen baru.

3. Mampu membedakan fakta dan opini.

4. Tekun dan ulet melakukan penelitian serta tidak mudah putus asa,

5. Teliti, cermat dan akurat tidak ceroboh dan tidak melakukan kesalahan dalam penelitian, sehingga didapatkan hasil yang benarbenar akurat.

6. Tidak mudah percaya jika tidak ada bukti yang mendukung.

7. Percaya pada prinsip bahwa kebenaran itu bersifat relatif, sehingga tidak memaksakan diri.

Sikap ilmiah dalam pembelajaran sains merupakan bagian dari sikap pada umumnya, dan sikap adalah bagian dari nilai, yaitu nilai kehidupan. Bila penamaan nilai kehidupan dalam pembelajaran sains terjadi berulang-ulang dan akhirnya menjadi milik peserta didik maka telah terjadi internalisi nilai-nilai sains.16

Pendekatan sikap dan nilai ilmiah serta keterampilan sains kemahiran insaniah (soft skill) dapat dilakukan dalam dua penekanan yang berbeda. Yang pertama melibatkan usaha untuk mengembangkan berbagai sikap tersebut yang dilihat sebagai sifat-sifat ilmuwan yang bila dikembangkan akan membantu siswa menyelesaikan persoalan sejenis seperti halnya ilmuwan menyelesaikannya.

Penekanan yang kedua adalah mengembangkan sikap-sikap khusus terhadap alam sekitar, mata pelajaran selain sains atau pun dasar untuk karir masa depan seperti halnya sikap terhadap sains.

Berbagai sikap dan kemahiran diatas secara jelas hubungannya dengan sainss, dan akan berpotensi terus berkembang khusunya ketika siswa terlibat dalam pelajaran sainss di sekolah. Namun terdapat juga sikap-sikap positif lainnya yang mana seorang guru sainss dapat juga meneguhkan dan memperkuatnya seperti rasa tanggung jawab, kesedian untuk bekerja sama, toleransi, percaya diri, menghargai orang lain, kebebasan, dapat dipercaya dan kejujuran intelektual. Berbagai kemahiran insaniah (soft skill) ini sangat

16Sukardjo, Optimalisasi Pendidikan Nilai/Karakter Dalam Pendidikan Sains Masa Depan, Makalah Seminar Nasional, pada tanggal 23 Oktober 2010 PPS Universitas Negeri Yogyakarta hlm. 3 
penting untuk membuat lulusan sekolah lebih bernilai dalam dunia yang berubah dengan cepat. ${ }^{17}$

1. Pendekatan Keterampilan Proses Sains di MI/SD

Pendekatan keterampilan proses merupakan pendekatan pembeiajaran yang menekankan pada proses belajar, aktivitas dan kreativitas peserta didik dalam memperoleh pengetahuan, keterampilan, nilai dan sikap, serta menerapkannya dalam kehidupan sehari-hari. Dalam pengertian tersebut, termasuk di antaranya keterlibatan fisik, mental, dan sosial peserta didik dalam proses pembeiajaran, untuk mencapai suatu tujuan. Menurut Mulyasa (2007), indikator-indikator pendekatan keterampilan proses antara lain kemampuan mengidentifikasi, mengklasifikasi, menghitung, mengukur, mengamati, mencari hubungan, menafsirkan, menyimpulkan, menerapkan, mengkomunikasikan, dan mengekpresikan diri dalam suatu kegiatan untuk menghasiikan suatu karya.18

Menurut Sri Sulistyorini (2007), kemampuan-kemapuan yang menunjukan keterlibatan peserta didik dalam kegiatan pembelajaran tersebut dapat dilihat melalui partisipasi dalam kegiatan pembelajaran berikut :

a. Kemampuan bertanya atau menemukan masalah

b. Kemampuan melakukan pengamatan

c. Kemampuan mengidentifikasi dan mengklasifikasi hasil pengamatan

d. Kemampuan menafsirkan hasil indentifikasi dan klasifikasi

e. Kemampuan mengukur

f. Kemampuan merencanakan dan melaksanakan suatu kegiatan penelitian

g. Kemampuan mengunakan dan menerapkan konsep yang telah dikuasai dalam suatu situasi baru

h. Kemampuan menyajikan atau mengkomunikasikan suatu hasil pengamatan dan atau hasil penelitian. ${ }^{19}$

Kegiatan-kegiatan yang dapat dilakukan untuk mendorong aktivitas dan kreativitas peserta didik dalam pembelajaran antara lain : diskusi: pengamatan, penelitian, praktikum. tanya jawab, karya wisata, studi kasus, bermain peran, dan kegiatan-kegiatan lain yang dapat menunjang tercapainya tujuan pembelajaran.

${ }^{17}$ Sumintono, Bambang, Pembelajaran Sains, Pengembangan Keterampilan Sains Dan Sikap Imiah Dalam Meningkatkean Kompetensi Guru, Jurnal Pendidikan Guru Madrasab Ibtidaiyah. Vol 2. No. 1, Juni 2010.hlm. 71-72

${ }^{18}$ TIM. Lapis PGMI, Pembelajaran IPA 1, (Learning Assistance Program for islamic shool, Jakarta, 2008) hlm. 8

${ }^{19}$ TIM. Lapis PGMI, Pembelajaran IP A ..., hlm. 8 
2. Pembelajaran Sains di Madrasah Ibtidaiyah/Sekolah Dasar

Kata pembelajaran adalah terjemahan dari instruction, yang banyak dsainskai dalam dunia pendidikan di Amerika Serikat. Istilah ini banyak dipengaruhi oleh aliran psikologi kognitif holistik, yang menempatkan siswa sebagai sumber kegiatan. Selain itu, istilah ini juga dipengaruhi oleh perkembangan teknologi yang diasumsikan dapat mempermudah siswa mempelajari segala sesuatu lewat berbagai macam media, seperti bahanbahan cetak, program telivisi, gambar, audio, dan lain sebagainya, sehingga semua itu mendorong terjadinya perubahan peranan guru dalam mengelola proses belajar mengajar, dari guru sebagai sumber belajar menjadi guru sebagai fasilitator dalam belajar mengajar. ${ }^{20}$

\section{Pendidikan Karakter Di Indonesia}

Jika kita tilik dari pengalaman sejarah bangsa, pendidikan karakter sesungguhnya bukan hal baru dalam tradisi pendidikan di Indonesia. Beberapa pendidik Indonesia modern yang kita kenal, seperti R.A. Kartini, Ki Hadjar Dewantara. Soekarno. Hatta, Tan Malaka, Moh. Natsir, dll, telah mencoba menerapkan semangat pendidikan karakter sebagai pembentuk kepribadian dan identitas bangsa sesuai dengan konteks dan situasi yang mereka alami.

Membentuk wajah bangsa merupakan keprihatinan pokok para cendekiawan kita. Dengan caranya masing-masing, mereka mencoba membayangkan dan menggagas sebuah bangsa yang memiliki identitas. Kalau kita mau menengok sedikit ke belakang dan melihat bagaimana awal munculnya kebangkitan nasional, kita akan menemukan bahwa bangsa ini terbentuk bukan terutama karena praksis perjuangan melawan penjajah yang tersebar secara sporadis di seluruh tanah air.

Sebagai pendidik bangsa, Soekarno tidak ingin bahwa bangsa ini memiliki mental budak yangenggan pada keinginan merdeka. Untuk inilah, semangat menyala-nyala tentang kemerdekaan itu harus dinyalakan dahulu dalam sanubari rakyat. Tanpa semangat merdeka, tidak akan daya apa- apa untuk mengubah nasib.

"Djikalau kita ingin mendidik rakjat Indonesia ke arah kebebasan dan kemerdekaan, djikalau kita ingin mendidik rakjat Indonesia menjadi tuan di atas dirinja sendiri, maka pertama-tama haruslah kita membangun-bangunkan dan mernbangkit-bangkitkan

\footnotetext{
${ }^{20}$ Sanjaya, W. Strategi pembelajaran berorientasi standar proses pendidikan. (Jakarta: Kencana Prenada Media.2006).
} 
dalam hati sanubari rakjat Indonesia itu ia punja Roch dan Semangat tnenjadi Roch-Merdeka dan Semangat- Merdeka jang sekeras-kerasnya, jang harus pula kita hidup-hidupkan mendjadi api kemauan merdeka jangsehidup-hidupnja! Sebab hanja Roch- Merdeka dan SemangatMerdeka jangsudah bangkit mendjadi Kemauan- Merdeka sahadjalah jang dapat meiahirkan sesuatu perbuatan-Merdeka jang berhasil." (dalam Sulub Indonesia Muda, 1928).

Inilah sesungguhnya yang menjadi cita-cita dasar Soekarno sejak sebelum kemerdekaan. Karakter bangsa tidak akan terwujud jika prasyarat pokoknya, yaitu kemerdekaan, tidak ada. Tidak ada sebuah bangsa yang bertanggung jawab jika tidak memiliki kemerdekaan. Tidak ada kemerdekaan jika dalam mentalitas bangsa tidak ada semangat merdeka atau kemauan merdeka. ${ }^{21}$

\section{E. Membangun Karakter Unggul Dalam Pembelajaran Sains}

Dalam membangun karakter ungul dalam pembelajaran sains diperlukan pendekatan yang sesuai dengan karakteristik dan cocok untuk peserta didik. Menurut (Mc Dermott, 1996) Pertama dengan menggunakan pendekatan inkuiri seperti yang disarankan oleh banyak ahli. Pendekatan ini dipilih dengan pertimbangan hasil penelitian menunjukan pendekatan inkuiri ini dapat memfasilitasi siswa untuk memecahkan masalah melalui penyelidikan ilmiyah, sehingga siswa dapat menemukan sendiri jawabannya. ${ }^{22}$

Tujuan umum dari pembelajaran sains dengan pendekatan inquiri, menurut Joyce et al. (1992) adalah untuk membantu siswa mengembangkan kemampuan yang diperlukan untuk membangkitkan pernyataan yang muncul dari rasa keingintahuannya dan upaya mencari jawabanya. Proses mencari jawaban tersebut merupakan kegiatan pemecahan masalah. Kompetensi memecahan masalah yang dapat dikembangkan ini memiliki indikator antara lain :

1. Mengekplorasi dan merumuskan maslah,

2. Mengusulkan hipotesis

3. Mendesains dan melaksanakan cara pengujian hipotesis,

${ }^{21}$ Doni Koesoema A., Pendidikan Karakter Strategi Mendidik. Anak di Zaman Global (Jakarta: Grasindo. 2010) hlm. 44-47

22Wiyanto, Pembelajaran Sains Untuk Mengembangkan Karakter Unggul, Makalah Seminar Nasional, pada tanggal 16 April 2011 Prodi Pendidikan IPA S1 FPMIPAUniversitas Negeri Semarang. Hlm. 3 
4. Mengorganisasikan dan menganalisis data yang diperoleh, menarik kesimpulan. ${ }^{23}$

a. Hasil dan Pembahasan Model Pengembangan Soft Skill

Bentuk atau model pengembangan soft skill yang saya buat dan kembangkan serta dilaksanakan sesuai dengan model yang direncanakan sejak awal dalam penyususnan penelitian ini, bentuk atau model soft skill yang saya gunakan adalah sebagai berikut:

Model Soft Skill yang dikembangkan

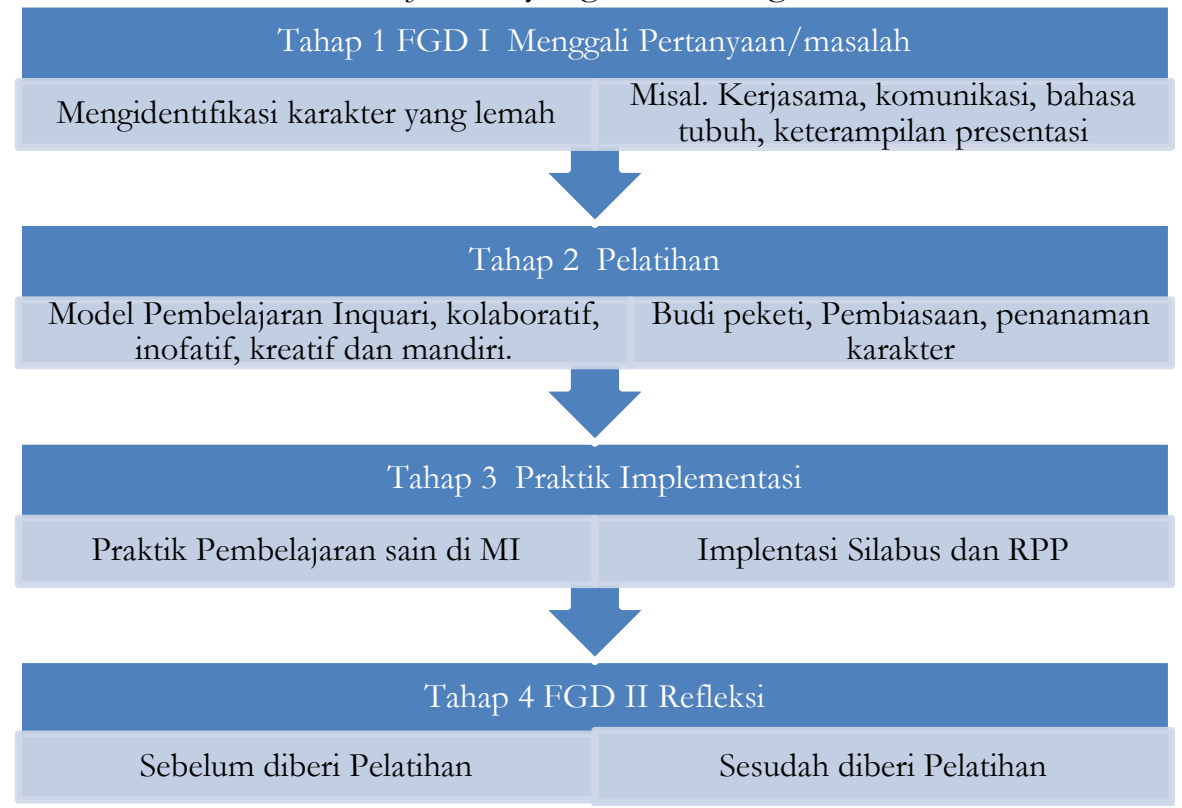

Tahapan yang pertama adalah bagaimana menggali pertanyaan dan pemasalahan mahasiswa dilapangan baik dalam pembelajaran atau permasalahan yang lainnya terkait dengan masalah akademik. Misalnya bagaimana mengdentifikasi intra dan inter personal yang masih lembah seperti belum memiliki karekter yang kuat, komunikasi yang kurang efektif dll. Tahap kedua adalah tahap pelatihan, tahap ini termasuk tahap inti dari pengembangan soft skill mahasiswa. Karena tahap ini tahap yang paling berat karena merubah maind set atau sudut pandang dari yang belum baik merubah menjadi baik. Seperti menanamkan pembisaan, penanaman karakter atau budi pekerti. Dalam pembelajaran sains menggunakan metode saintifik dengan pendekatan keterampilan proses, pendekatan SETS dan model kooperatif, aktif learning dll.

${ }^{23}$ Wiyanto, Pembelajaran Sains ...., Hlm. 4 
Tahap ketiga adalah tahap praktek implementasi pembelajaran soft skill pada pelajaran sain di MIN. Tahap ke empat merupakan tahap FGD II atau tahap Refleksi dan sekaligus tahap akhir dari model soft skill yang saya kembangkan.

Setelah saya uji coba dilapangan ternya sangat efektif dan mudah digunakan dengan model soft skill dalam pembelajaran sains ini.

A. Hasil dan Pembahasan Tahap 1 FGD I

Dari hasil Forum Group Discation 1 (FGD) yang dilaksanakan hari minggu tanggal 15 September 2013 pukul 12.00-16.00 Wib. Mahasiswa diajak berdiskusi dan ditanya jawab seputar soft skill yang mereka ketahui, dan mereka diajak untuk mengungkapkan masalah atau kekurangankerurangan dari pembelajaran sains di Madrasah Ibtidaiyah, lalu mereka mengungkapkan dengan lisan dan tulisan. ini hasilnya setelah saya analisis dan saya resum, karena ada beberapa kesamaan atau kemiripan yang hampir persis sama sehingga harus direduksi.

Nilai yang perlu ditanamkan dan dihidupkan dalam pembelajaran sains di MIN Wonosari Gunungkidul Yogyakarta adalah :

1. Semangat dan senang.

2. Kreatif (guru dituntut kreatif dalam pembelajran sains).

3. Rasa ingin tahu, mandiri, berani mencoba, terus belajar, menghadapi tantangan.

4. Berani mencoba (tidak takut salah), rasa ingin tahu, mandiri.

5. Dibiasakan disiplin, tangung jawab.

6. Rasa ingin tahu, Tanggung jawab, Antusias, Tekun dan Percaya diri.

7. Rasa ingin tahu, mandiri, berani mencoba, tanggung jawab.

8. Keseriusan, Rasa ingin tahu, Tanggung jawab, berani mencoba, semangat

9. Proaktif, atusias dan tanggung jawab

10. Senang, kreatif, semangat belajar, berani mencoba

Dari sepuluh nilai ini, yang akan dilatih memlalui pengembangan soft skill calon guru ini. Dan setelah dilatih mereka langsung memimplementasikan di MIN I Wonosari dan MIN Patuk kab. Gunung kudil Yogyakarta, serta MIN 1 Yogyakarta.

B. Hasil dan Pembahasan Tahap 2 Pelatihan atau Tahap Inti

Dari hasil pelatihan Soft skill yang dilaksanakan pada hari senin tanggal 23 September 2013. Pelatihan pengembangan soft skill dengan 
menekankan pada materi berikut ini : Dalam soft skill terbagi menjadi dua yaitu interpersonal skill dan intrapersonal skill.

Dari materi tersebut diatas yang lebih ditekankan adalah materi Communication skills, Motivation skills, Presentation skills, dan Transforming Character ini yang paling dibutuhkan oleh mahasiswa dari permasalahan yang diungkapkan diatas. Hasil penelitian menunjukan bahwa pelatihan kompetensi kepribadian dan kompetensi social (soft skill) terdapat pengaruh terhadap perubahan pada karakter tertentu pada mahasiswa yang dilatih di kampus dan sekolah. Perubahan karakter tertentu pada mahasiswa dipengaruhi oleh beberapa faktor diantaranya faktor internal dan eksternal. Faktor internal antaralain minat, motivasi, membuka diri untuk memperbaiki pengembangan diri. Sedangkan faktor eksternal antaralain lingkungan akademik sekolah, lingkungan keluarga dan lingkungan masyarakat.

Faktor-faktor kelebihan diberikan pelatihan kompetensi kepribadian dan sosial (soft skill) yang berupa:

1. Mahasiswa mampu untuk memahami orang lain, perspektif orang lain, dan berminat terhadap kepentingan orang lain juga.

2. Mahasiswa telah mampu untuk memahami sikap inklusif, bertindak objektif, serta tidak diskriminatif berdasarkan jenis kelamin, agama, ras, kondisi fisik, latar belakang keluarga, dan status sosial ekonomi.

3. Mahasiswa telah mampu menerima dan mematuhi norma agama, hukum, sosial, dan kebudayaan nasional Indonesia.

4. Mahasiswa telah mampu bekerja sama dan bertanggung jawab atas kinerja pribadi.

5. Berpenampilan diri sebagai pribadi yang jujur, berakhlak mulia, dan teladan bagi peserta didik dan masyarakat.

Ada beberapa faktor yang masih terlihat lemah diantaranya kompetensi kepribadian dan sosial yang berupa:

2. Selalu berpakaian rapi (Baju disetrika, celana disetrika, sepatu disemir, rambut disisir rapi dan kewajaran) masih perlu ditingkatkan dengan adanya pembiasaan-pembiasaan yang baik dan control yang lebih baik lagi.

3. Masih rendah menyampaikan gagasan dan informasi secara akurat, menarik dan jelas dalam proses pembelajaran (Kemampuan berkomunikasi). Masih banyak yang terlihat apatis dalam berkomunikasi dilingkungan sekolah contohnya tegur sapa (Belum 
menyapa terlebih dahulu) dengan teman-teman, guru-guru, karyawan dan siswa.

4. Belum mampu menjadi model peran disekolah (Keteladanan) contohnya dalam hal berpakaian, bahasa tubuh, dan komunikasi secara lisan.

5. Masih belum mampu memulai dan mengelola perubahan yang ada dilingkungan akademik sekolah.

6. Masih rendah bernegosiasi dan mengatasi silang pendapat dalam kolompok mahasiswa itu sendiri.
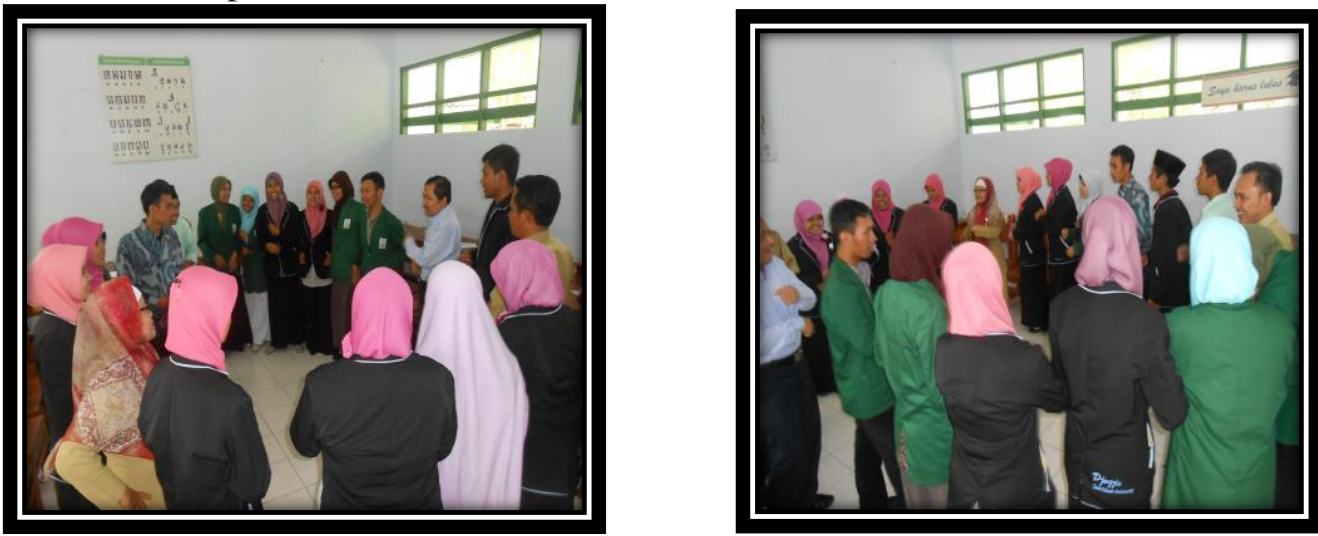

Pelaksanaan pelatihan pengembangan soft skill berjalan dengan baik, para mahasiswa mengikuti dengan senang dan ceria karena materi yang diberikan sesuai dengan apa yang ia butuhkan dan mereka sebelumnya belum pernah mendapatkan pelatihan seperti ini, dari hasil pelatihan menghasilkan perubahan personal, karakter, dan secara dokumen menghasilkan silabus dan rencana pelaksanaan pembelajaran, media pembelajaran sederhana yang digunakan saat pembelajaran sains.

\section{Hasil dan Pembahasan Tahap 3 Implementasi pembelajaran}

Tahap implemantasi soft skill dalam pembelajaran sains dilaksanakan di MIN 1 Wonosari Gunungkidul pada tanggal 24 September sampai dengan 2 oktober 2013. Pengamatan dilakukan selama proses pembelajaran sains berlangsung. 


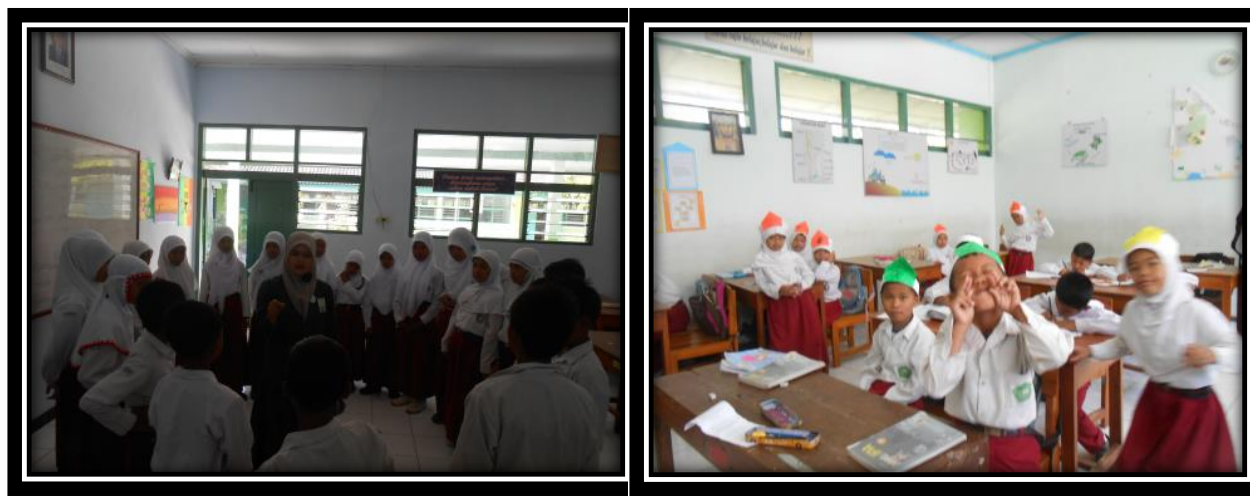

Tahap implemantasi soft skill dalam pembelajaran sains dilaksanakan dengan cara bergiliran, satu maju yang lain melihat dan mengobservasi dengan lembar penilai observasi pembelajaran yang sudah dibuat dan dihasilkan rata-rata mendapatkan skor 112 dengan kategori baik "B". Dan yang tertinggi adalah skor 118. Ini Saya contohkan salah satu mahasiswa bernama "siswi" menyampaikan pembelajaran di kelas IV B tentang materi materi "Daur Hidup Beberapa Hewan", strategi pembelajaran yang digunakan adalah interactive lecturing yang dipadukan dengan bernyanyi dan role playing.
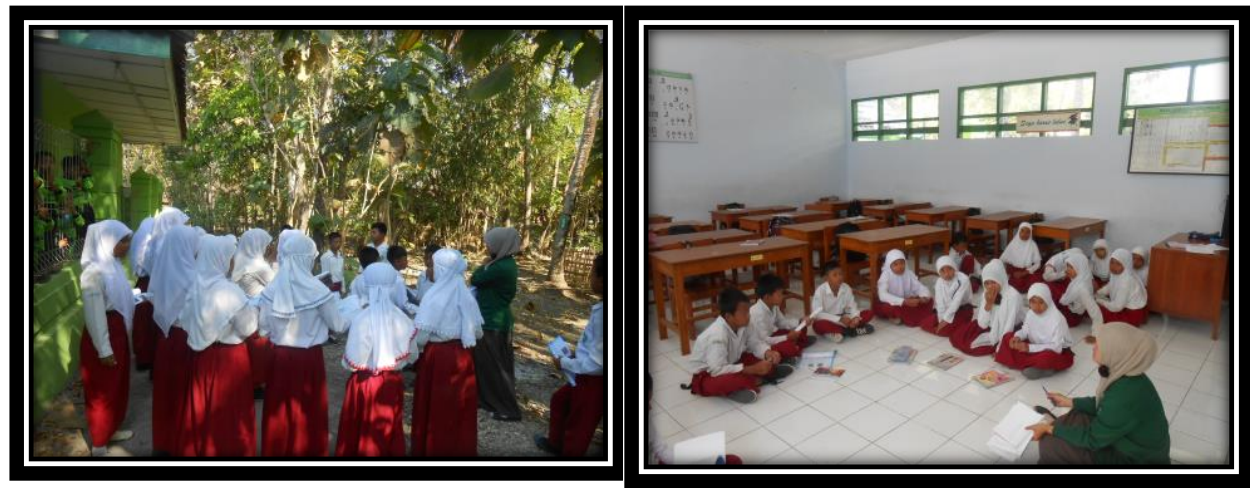

Dari hasil observer dalam pembelajaran mulai dari prapembelajaran yaitu mengecek kesiapan siswa untuk belajar. Sudah dikondisikan dengan baik dengan senyum, salam, sapa, sopan dan santun, ini merupakan sudah termasuk perubahan yang semulanya belum tersentuh ini dimunculkan saat pembelajaran, lalu menyampaikan indikator apa yang hendak dicapai dalam pembelajaran, penyampaian materi sudah sangat menguasai dan dapat menghubungkaitkan dengan ilmu lain seperti teknologi, lingkuan dan 
masyarakat. Dalam menyampaikan dengan runtut sesuai dengan hirarki pembelajaran dari yang mudah sampai ke yang sulit. Sesuai dengan apayang direncanakan dalam RPP (rencana pelaksanan pembelajaran) dan sesuai dengan tujuan pembelajaran yang sudah ditetapkan sebelumnya. Dalam pembelajaran sudah kelihatan membiasakan dengan kata-kata yang positif disampaikan kepada siswa. Disamping itu juga menggunakan media yang mudah dipahami siswa dan efektif penggunaanya serta sederhana tetapi membutuhkan kekreatifan yang tinggi. Dalam menggunakan media siswa juga telibat langsung merasakannya sehingga menimbulkan kesan yang positif terhadap pembelajaranya. Dalam pembelajaran menimbulkan kegembiraan dan keceriaan saat belajar berlangsung. Mahasiswa menilai dengan outentik assesmen dari keikut sertaan dan keaktifan dalam pembelajaran berlangsung. Bahasa yang digunakan menggunakan bahasa yang jelas, baik, dan benar sesuai dengan gaya bahasanya masiswa masingmasing. Di akhir kegiatan pembelajaran siswa bersama mahasiswa membuat kesimpulan dan memberikan tugas untuk membaca buku halaman selanjutnya untuk pertemuan yang akan datang.

Gambaran tentang peningkatan kualitas proses pembelajaran, Dari hasil pengamatan terhadap siswa dalam proses pembelajaran berlangsung menunjukan:

1. Siswa antusias dalam mempelajari.

2. Siswa termotivasi untuk mencari sumber-sumber belajar.

3. Siswa terdorong untuk bekerja sama dalam kelompok

4. Siswa terdorong untuk memecahkan masalah (problem solving) dan melaksanakan tugas-tugas kelompok.

5. Dorongan rasa ingin tahu untuk belajar sangat besar.

6. Keberanian siswa didalam pembelajaran sudah mulai tumbuh misalnya keberanian untuk bertanya, tampil kedepan, dll.

Dari hasil observasi dan pengamatan peneliti saat pembelajaran sains dikelas ataupun diluar kelas. Nilai karakter dan soft skill yang sudah mulai tumbuh adalah :

1) Keberanian siswa untuk maju kedepan dan saat berperan serta atau partisipasi dalam mengikuti pembelajaran.

2) Siswa sangat senang mengikuti pelajaran sains.

3) Siswa dalam belajar sudah mulai diajak tersenyum dalam belajar, ini berarti sudah menggunakan soft skill dengan bahasa tubuh dan komunikasi.

4) Siswa dalam belajar diajak bermain dan bernyayi. 
5) Siswa sangat senag dalam belajar sambil bermain dan bernyayi karena siswa sangat cocok dengan gaya belajarya siswa.

6) Mahasiswa kreatif dalam menyusun rencana pelaksanaan pembelajaran (RPP).

7) Mahasiswa merasa bersemangat, dan senang dalam melaksanakan pembelajaran.

8) Mahasiswa merasa percaya diri, tanggung jawab, disiplin, kerja sama, tertib, serius atau fokus.

9) Mahasiswa dalam memberikan pembelajaran sudah menggunakan eksperimen dalam pembelajaran di kelas.

10) Mahasiswa dalam memberikan pembelajaran sudah sangat fariatif dan tidak monoton dikelas saja. Menggunakan strategi Iquiri terbimbing.

D. Hasil dan Pembahasan Tahap 4 Refleksi atau Akhir

Dari hasil Forum Group Discation 2 (FGD) yang dilaksanakan hari Jumat tanggal 18 dan 25 Oktober 2013 pukul 13.30 - 16.30 Wib dengan agenda mencerikan kejadian setelah dilatih Soft Skill dan di implementasikan dalam pembelajaran sains di Madrasah Ibtidaiyah. Berikut ungkapan dari mahasiswa yang telah dilatih Soft Skill dan melakukannya.

Dari hasil pencurahan refleksi diatas ada beberapa hal yang belum sempat menyampain untuk mengimplementasikan pembelajaran karena waktu kita yang terbatas, waktu yang diberikan sekolah juga tidak bisa leluasa menggukan sepenuhnya, kerana harus melaksanakan sesuai dengan kalender akdemik yang sudah direncanakan, hanya di ijinkan beberapakali saja dalam mempraktekkan. 
E. Kesimpulan

Kesimpulan yang dapat diambil dari penelitian pengembangan ini adalah:

1. Model Pengembangan soft skill adalah model tahapan, yang terdiri dari empat tapan. Mulai dari tahap ke-1 Forum group discation FGD 1 penyampaian masalah (kemampuan bertanya); tahap ke-2 Pelatihan soft skill ; tahap 3 implementasi pembelajaran dan tahap 4 FGD II atau refleksi. Penerapan model soft skill sangat efektif untuk diterapkan di semua rumpun pelajaran sain di MI.

2. Pelaksanaan pelatihan pengembangan soft skill berjalan dengan baik, para mahasiswa mengikuti dengan senang dan ceria karena materi yang diberikan sesuai dengan apa yang ia butuhkan dan mereka sebelumnya belum pernah mendapatkan pelatihan seperti ini, dari hasil pelatihan menghasilkan perubahan personal, karakter, dan secara dokumen menghasilkan silabus dan rencana pelaksanaan pembelajaran, media pembelajaran sederhana yang digunakan saat pembelajaran sains.

3. Dari hasil observasi dalam pembelajaran sains yang sudah dimplementasikan di MIN 1 Wonosari rata-rata mendapat skor 115 dengan kategori baik “B”. Dan pembentukan karakter sudah mulai kelihatan perubahanya diantaranya : atusias siswa meningkat, rasa ingin tahu sudah tumbuh, terdorong untuk bekerja sama dalam kelompok dan terdorong untuk memecahkan masalah (problem solving). 


\section{SUMBER PUSTAKA}

Ade Armando, dkk. Refleksi Karakter Bangsa. (Jakarta: Forum Kajian Antropologi Indonesia. 2008).

Anna Poedjiadi. Sainss Teknologi Masyarakat. (Bandung: PT Remaja Rosdakarya. 2005).

Adam, G., R. Social Competence During Adolescence: Social Sensitivity, Locus Of Control, And Peer Popularity. Journal Of Yoauth And Adolescence. Vol. 12, No 03, 1983.

Adi Suryanto dan Yuni Tri Hewindati, Pemahaman Murid Sekolah Dasar terhadap Konsep IPA Berbasis Biologi:Suatu Diagnosis Adanya Miskonsepsi, Jurnal Pendidikan, Vol.5, No.1, Lembaga Penelitian Universitas Terbuka, Jakarta: Maret 2004.

Anik Ghufron, Pengembangan Kurikulum Teaching School Berbasis Profesi, 2010 Makalah Seminar dan Loka Karya Fakultas Tarbiyan dan Keguruan UIN Sunan Kalijaga Yogyakarta, pada tanggal 29 November 2010.

Arikunto, Suharsimi. Prosedur Penelitian, Jakarta: Rineka Cipta. 1998.

Christina McCale, It's Hard Work Learning Soft Skills: Can Client Based Projects Teach the Soft Skills Students Need and Employers Want?. The Journal of Effective Teaching, Vol. 8, No. 2, 2008, 50-60

Dewi Padmo, Purwanto, dan Ida M Sadjadi. Peningkatan Kualitas Belajar melalui Teknologi Pembelajaran. (Jakarta: Pusat Teknologi Komunikasi dan Informasi Pendidikan.2004).

Dede Rosyada, Paradigma Pendidikan Demokrasi, Prenada Media, Jakarta.

Doni Koesoema A., Pendidikan Karakter Strategi Mendidik Anak di Zaman Global (Jakarta: Grasindo. 2010)

Dahar, Ratna Wilis. Teori-teori Belajar, (Bandung: Erlangga, 1991)

Drost, Peter J.I.G.M. Pendidikan Sainss Yang Humanistis. Yogyakarta: Kanisius. (2003).

Denham, S., A., \& Queenan, P., 2003. Preschool Emotional Competence: Pathway To Social Competence. Journal Of Child Development. Vol. 74, No 1, 238-256.

Direktorat Tenaga Kependidikan. Mengenal, Mengembangkan, Dan Memberdayakan Diri, Jakarta. 2009 
Djoko Hari Nugroho, Integrasi Soft Skills Pada Kurikulum Prodi Elektronika Instrumentasi-STTN Untuk Persiapan SDM PLTN, Makalah Seminar Nasional V SDM Teknologi Nuklir Yogyakarta, ISSN 1978-0176; 5 November 2009

Elfindri dkk. Soft Skill Untuk Pendidik, (Jakarta: Baduose Media, 2011).

Tasman Hamami. Pengembangan Soft Skill Bagi Guru Profesional, Makalah Pembekalan sertifikasi guru dalam jabatan UIN Sunan Kalijaga Yogyakarta 2010.

Hairuzila Idrus, Challenges in the Integration of Soft Skills in Teaching Technical Courses: Lecturers' Perspectives, Asian Journal of University Education. ISSN 1823-7797 Vol. 5 No. 2, 2009, 67-81

Horsley, S.L., Love, N., Stiles, K.E. et al. Designing professional development for teachers of science and mathematics $\left(2^{\text {rd }}\right.$ ed.). (California: Corwin Press, 2003).

Imam Suprayogo, Mengintegrasikan Nilai-Nilai Lubur Dalam Pendidikan Sainss Untuk Menyongsong Masa Depan Bangsa, Makalah Seminar Nasional, pada tanggal 23 Oktober 2010 PPS Universitas Negeri Yogyakarta. 2010 .

Irawan, Prasetya. Logika dan Prosedur Penelitian, STIA LAN Press. Jakarta. 1999.

Koesoema A. Doni, Pendidikan Karakter, (Jakarta: Grasindo. 2010).

Liliasari. Membangun Masyarakat Melek Sainss Berkarakter Bangsa Melalui Pembelajaran. Makalah Seminar Nasional, pada tanggal 16 April 2011 Prodi Pendidikan IPA S1 FPMIPAUniversitas Negeri Semarang.

Martin, R., Sexton, C., Franklin, T., et al. Teaching science fol all children: Inquiry methods for constructing understanding (3 ${ }^{\text {rd }}$ ed.). (Boston: Pearson Education, Inc. 2005).

Martani, W., \& Adiyanti, M., G. Kompetensi Sosial Dan Kepercayaan Diri Remaja. Laporan Penelitian (Tidak Diterbitkan). Fakultas Psikologi Universitas Gajah Mada. Yogyakarta.1990.

Mudhofir, Ali. Modul Pengembangan Profesionalisme Guru, Dirtjen Pendis. Kemenag RI. Jakarta : 2011.

Muqowin, Pengembangan Soft Skill Guru.( Yogyakarta: Pedagogia, 2011) 
Nana Sudjana. Penilaian Hasil dan Proses Belajar Mengajar. (Bandung: Remaja Rosdakarya, 2010)

Paul Suparno, Integrasi Pendidikan Nilai/Karakter Dalam Pendidikan Sainss Masa Depan, Makalah Seminar Nasional, pada tanggal 23 Oktober 2010 PPS Universitas Negeri Yogyakarta.

Priyanto, Slamet. Dengan Pendidikan Karakter, Terbangun Peradaban Lubur. diakses tanggal 20 desember 2010 http://suaramerdeka.com/v1/index.php/pendidikan/newsdetail/ 48534

Ra'uf, Kurikulum 2004 Sekolah Menengah Pertama (Jakarta: Dharma Bhakti. 2005).

Rekewil Pimpinan PTS, 2006. Soft Skill di Perguruan Tinggi, Hand Out.

Saldi Fadli , Sinergi Soft Skill dan Hard Skill, diakses tanggal 20 desember 2010 http://edukasi.kompasiana.com/2010/02/23/sinergi-softskill-dan-hard-skill/

Sanjaya, W. Strategi pembelajaran berorientasi standar proses pendidikan. (Jakarta: Kencana Prenada Media.2006).

Sumaji dkk,. Pendidikan Sainss Yang Humanistis. (Yogyakarta: Kanisius. 2009).

Sumintono, Bambang, Pembelajaran Sains, Pengembangan Keterampilan Sains Dan Sikap Ilmiah Dalam Meningkatkan Kompetensi Guru, Jurnal Pendidikan Guru Madrasah Ibtidaiyah. Vol 2. No. 1, Juni 2010.

Sulistyorini, Sri. Model Pembelajaran SAINS Sekolab Dasar dan Penerapannya dalam KTSP, (Yogyakarta, Tiara Wacana2007).

Sukardjo, Optimalisasi Pendidikan Nilai/Karakter Dalam Pendidikan Sainss Masa Depan, Makalah Seminar Nasional, pada tanggal 23 Oktober 2010 PPS Universitas Negeri Yogyakarta.

Sardiman A.N., Interaksi dan Motivasi Belajar Mengajar, PT.Raja Grafindo Cipta, Jakarta: 2003

Slameto, Belajar dan Faktor-faktor yang Mempengarubinya, PT.Rineka Persada, Jakarta. 2004Sukardjo dan Lis Permana Sari. Penilaian Hasil Belajar Kimia (Yogyakarta: FMSAINS UNY, 2008).

Nana Sudjana, Dasar-dasar Proses Belajar Mengajar, PT.Sinar Baru Algesindo, Bandung: 2000. 
Nana Saudih Sukmadinata, Landasan Psikologi Proses Pendidikan, PT.Remaja Rosda Karya, Bandung. 2003.

Nur Syam. Pendidikan Soft Skill, Artikel ilmiah diakses pada tanggal 20 Desember 2010 http:// nursyam.sunan-ampel.ac.id/?p=1585.

Tim. Fakultas Tarbiyan dan Keguruan, Pengembangan Soft Skill Bagi Guru Profesional, Makalah Pembekalan sertifikasi guru dalam jabatan UIN Sunan Kalijaga Yogyakarta 2010.

Widji Seoratri, Implementasi Soft Skill Dalam Pembelajaran, (Universitas Airlangga, 2009).

Wiyanto, Pembelajaran Sains Untuk Mengembangkan Karakter Unggul, Makalah Seminar Nasional, pada tanggal 16 April 2011 Prodi Pendidikan IPA S1 FPMIPAUniversitas Negeri Semarang. 